\title{
CaSR activates PKCS to induce cardiomyocyte apoptosis via ER stress-associated apoptotic pathways during ischemia/reperfusion
}

\author{
CHONG LIU ${ }^{1,2^{*}}$, HUANMING $\mathrm{LI}^{3 *}$, HUISHUANG ZHENG ${ }^{4}$, MEILI ZHAI ${ }^{5}$, \\ FANGHAO LU ${ }^{2}$, SHIYUN DONG ${ }^{2}$, TAO FANG $^{6}$ and WEIHUA ZHANG ${ }^{2}$
}

\author{
${ }^{1}$ Department of Anesthesiology, Central Laboratory, Tianjin 4th Centre Hospital, The Fourth Central Hospital \\ Affiliated to Nankai University, The Fourth Center Clinical College of Tianjin Medical University, Tianjin 300140; \\ ${ }^{2}$ Department of Pathophysiology, Harbin Medical University, Harbin, Heilongjiang 150081; ${ }^{3}$ Department of Cardiology, \\ Tianjin 4th Centre Hospital, The Fourth Central Hospital Affiliated to Nankai University, Tianjin 300140; \\ ${ }^{4}$ Department of Pathology, Haiyang Renmin Hospital, Haiyang, Shandong 265100; ${ }^{5}$ Department of Anesthesiology, \\ Tianjin Central Hospital of Gynecology Obstetrics, Central Gynecology Obstetrics Hospital of Nankai University, \\ Tianjin 300052; ${ }^{6}$ Central Laboratory, Tianjin 4th Centre Hospital, The Fourth Central Hospital \\ Affiliated to Nankai University, Tianjin 300140, P.R. China
}

Received October 17,2018; Accepted April 17, 2019

DOI: $10.3892 /$ ijmm.2019.4255

\begin{abstract}
Endoplasmic reticulum(ER) stress can be activated by ischemia/reperfusion (I/R) injury in cardiomyocytes. Persistent ER stress, with an increase in intracellular $\mathrm{Ca}^{2+}\left(\left[\mathrm{Ca}^{2+}\right] \mathrm{i}\right)$ concentration, leads to apoptosis. Protein kinase C (PKC) has a key role in myocardial damage by elevation of $\left[\mathrm{Ca}^{2+}\right]$ i. The calcium-sensing receptor (CaSR), a $\mathrm{G}$ protein-coupled receptor, can increase the release of $\left[\mathrm{Ca}^{2+}\right] \mathrm{i}$ from the ER through the inositol triphosphate receptor $\left(\mathrm{IP}_{3} \mathrm{R}\right)$. Intracellular calcium overload has been demonstrated to cause cardiac myocyte apoptosis during I/R. However, the associations between PKC, CaSR and ER stress are not clear. The present study examined the hypothesis that activation of PKC $\delta$ by CaSR participates in ER stress-associated apoptotic pathways within myocardial $\mathrm{I} / \mathrm{R}$. Rat hearts were subjected to $30 \mathrm{~min}$ of ischemia in vivo, followed by reperfusion for $120 \mathrm{~min} . \mathrm{GdCl}_{3}$ (a CaSR activator) was used to elevate the intracellular $\mathrm{Ca}^{2+}$ concentration, but the $\mathrm{Ca}^{2+}$ concentration in the ER was significantly decreased during I/R. Following exposure to $\mathrm{GdCl}_{3}$, expression levels of CaSR, glucose-regulated protein 78 (GRP78), Caspase-12, phosphorylated JNK and Caspase-3 were increased, and the ratios of apoptotic myocardial cells were significantly increased. By contrast, following exposure to rottlerin, a PKC $\delta$
\end{abstract}

Correspondence to: Professor Weihua Zhang, Department of Pathophysiology, Harbin Medical University, 157 Health Road, Nangang, Harbin, Heilongjiang 150081, P.R. China

E-mail: zhangwh116@126.com

${ }^{*}$ Contributed equally

Key words: calcium-sensing receptor, endoplasmic reticulum, ischemia/reperfusion, apoptosis, cardiomyocyte inhibitor, the expression levels of these proteins and the ratio of apoptotic myocardial cells were significantly reduced. The present study also demonstrated that PKC $\delta$ translocated into the ER to induce an ER stress response and participate in the ER stress-related apoptosis pathway. These results confirmed that CaSR activated PKC $\delta$ to induce cardiomyocyte apoptosis through ER stress-associated apoptotic pathways during I/R in vivo.

\section{Introduction}

There are different degrees of apoptosis in myocardial ischemia/reperfusion (I/R) injury. Reducing myocardial apoptosis has become a focus of research on myocardial protection. In 2003, Wang et al (1) first reported that calcium-sensing receptor (CaSR) was expressed in myocardial tissue, leading to the hypothesis that CaSRs participated in myocardial I/R injury induced by calcium overload (2); however, the specific mechanism remains unknown.

With I/R, CaSR activation of the phospholipase C (PLC) pathway causes calcium release from the endoplasmic reticulum (ER) (1,3-5), resulting in excessive ER stress (6). Multiple studies have demonstrated that the protein kinase C (PKC) family participates in the protection of cardiomyocytes or damage from myocardial I/R injury (5-7). The promotion or inhibition of apoptosis depends on the PKC subtype $(8,9)$. $\mathrm{PKC} \delta$, one of the PKC subtypes, is an important signal in multiple types of cells, including myocardial infarction (10), lung inflammation (11), development of atherosclerosis (12) and the salivary gland (13). Previous studies have confirmed that myocardial I/R injury results in the transfer of PKC $\delta$ from the cell cytoplasm to the mitochondria and ER $(5,7,14,15)$. During $\mathrm{I} / \mathrm{R}, \mathrm{CaSR}$ induces phosphorylation of $\mathrm{PKC} \delta$ and migrates to mitochondria to induce cardiomyocyte apoptosis (5); however, the mechanism by which PKCD participates in cell apoptosis has not been fully elucidated. The aim of the present study was 
to confirm that CaSR could activate PKC $\delta$ to induce cardiomyocyte apoptosis through ER stress-associated apoptotic pathways during I/R in vivo.

\section{Materials and methods}

Animals. Male Wistar rats, weighing 200-250 g, were obtained from the Animal Center of Harbin Medical University. All animals were treated according to the Guidelines for the Care and Use of Laboratory Animals and all protocols were approved by the Ethics Committee of Basic Medical College of Harbin Medical University. The associated permit number is SCXK (Hei) 2013-001.

Materials. NPS-2390, $\mathrm{GdCl}_{3}$, verapamil, rottlerin and amiloride were obtained from Sigma-Aldrich (Merck $\mathrm{KGaA}$ ). The terminal deoxynucleotidyl transferase (TdT)-mediated-UTP nick end labeling (TUNEL) kit, and the 5,5',6,6'-Tetrachloro-1,1',3,3'-tetraethylbenzimidazolocar bocyanine iodide (JC-1) kit were from Roche Diagnostics GmbH. Primary antibodies targeting PKC (cat. no. sc-213), glucose-regulated protein 78 (GRP78; cat. no. sc-13968), Caspase-12 (cat. no. sc-5627), c-Jun N-terminal kinase (JNK; cat. no. sc-474), phosphorylated (p-) JNK (cat. no. sc-6254) and Caspase-3 (cat. no. sc-7148) were obtained from Santa Cruz Biotechnology, Inc. The primary antibody targeting CaSR was from Alpha Diagnostic International Inc. (cat. no. ACR-004). $\beta$-actin (cat no. M01263-2) and Calnexin (cat. no. A03372) were obtained from Boster Biological Technology.

Experimental protocol. Heparinized rats $[2,000 \mathrm{U} / \mathrm{kg}$, by intraperitoneal (i.p.) injection] were anesthetized with $2 \%$ pentobarbital sodium ( $40 \mathrm{mg} / \mathrm{kg}$; i.p.). Following endotracheal intubation, an animal breathing machine was provided with a rodent respirator at a rate of 50 breaths $/ \mathrm{min}$ and a tidal volume of $20 \mathrm{ml} / \mathrm{kg}$ (16). Between the third and fourth ribs, a left parasternal incision was made to expose the heart. The left anterior descending artery (LAD) was ligated using a 6-0 silk suture. Myocardial I/R was induced by the compression of the LAD (17). The changes in the ST-T segment, caused by tightening or loosing of the silk suture, were monitored by ECG. After coronary artery ligation for $30 \mathrm{~min}$, the ligation was removed to restore myocardial blood perfusion. At $2 \mathrm{~h}$ after reperfusion, the rats were sacrificed by exsanguination under anesthesia, and aortic inverse irrigation with PBS was performed to the hearts in order to remove residual blood. Subsequently, a portion of the tissue of the anterior wall of the left ventricle near the apex was obtained for further analysis.

The animals were randomly divided into five groups: i) Control group $(n=10)$, thread only, without ligation; ii) $I / R$ group $(I / R ; n=10)$, coronary artery ligation for $30 \mathrm{~min}$, and loosening of the silk suture to restore myocardial blood perfusion for $2 \mathrm{~h}$; iii) $\mathrm{I} / \mathrm{R}+$ Amiloride+Verapamil $+\mathrm{GdCl}_{3}$ group $(\mathrm{I} / \mathrm{R}+\mathrm{A}+\mathrm{V}+\mathrm{Gd} ; \mathrm{n}=10), 20 \mu \mathrm{M}$ amiloride (inhibitor of $\mathrm{Na}^{+}-\mathrm{Ca}^{2+}$ exchanger), $1 \mu \mathrm{M}$ verapamil (L-type calcium channel blocker) and $30 \mu \mathrm{M} \mathrm{GdCl}_{3}$ (activator of CaSR) were added by injection through the femoral vein 10 min prior to reperfusion; iv) $\mathrm{I} / \mathrm{R}+$ Amiloride+Verapamil $+\mathrm{GdCl}_{3}+\mathrm{NPS}-2390$ group (I/R+A+V+Gd+NPS; $\mathrm{n}=10$ ), NPS-2390 (inhibitor of CaSR) was added by injection through the femoral vein $10 \mathrm{~min}$ prior to reperfusion, while all other procedures were the same as those performed in the I/R+Amiloride+Verapamil $+\mathrm{GdCl}_{3}$ group; and v) I/R+Amiloride+Verapamil $+\mathrm{GdCl}_{3}+$ Rottlerin group (I/R+A+V+Gd+PKCסI; $\mathrm{n}=10)$, amiloride $(20 \mu \mathrm{M})$, verapamil $(1 \mu \mathrm{M}), \mathrm{GdCl}_{3}(30 \mu \mathrm{M})$ and $10 \mu \mathrm{M}$ rottlerin (specific inhibitor of PKCס) were added by injection through the femoral vein $10 \mathrm{~min}$ before reperfusion, and all other procedures were identical to those performed in the I/R+Amiloride+Verapamil+Gd $\mathrm{Cl}_{3}+\mathrm{NPS}-2390$ group.

ER isolation. Frozen heart specimens were minced and ground by pestle on ice and then homogenized using a tissue homogenizer thirty times in $3 \mathrm{ml}$ of cool lysis buffer ( $250 \mathrm{mM}$ sucrose, $20 \mathrm{mmol} / 1 \mathrm{Tris}-\mathrm{HCl} \mathrm{pH} 7.2,10 \mathrm{mmol} / \mathrm{l} \mathrm{KCl}, 1.5 \mathrm{mmol} / 1$ $\mathrm{MgCl}_{2}, 1 \mathrm{mmol} / 1$ EDTA, 1:300 protease inhibitor cocktail, 1:300 phosphatase inhibitor cocktail). The muscle cells were then collected in a microcentrifuge tube and incubated for $30 \mathrm{~min}$ at $4^{\circ} \mathrm{C}$. The homogenates were centrifuged at $800 \mathrm{x} \mathrm{g}$ for $10 \mathrm{~min}$ at $4^{\circ} \mathrm{C}$, and the resulting supernatant was centrifuged at $10,000 \mathrm{xg}$ for $20 \mathrm{~min}$ at $4^{\circ} \mathrm{C}$. The new supernatants were centrifuged at $100,000 \mathrm{xg}$ for $1 \mathrm{~h}\left(4^{\circ} \mathrm{C}\right)$ to obtain the ER (pellet) and cytosolic (supernatant) extracts. The ER pellet was resuspended in lysis buffer containing 1\% Triton X-100 (14). The ER extract was stored at $-70^{\circ} \mathrm{C}$.

TUNEL staining. Identification of apoptotic cells was performed using an in situ cell death detection kit (Roche Diagnostics $\mathrm{GmbH}$ ), according to the manufacturer's instructions. After rinsing with PBS, the heart specimens were fixed with $4 \%$ formaldehyde solution at room temperature for $24 \mathrm{~h}$. Following routine protocols, the heart specimens were paraffin-embedded, sectioned at $4 \mu \mathrm{m}$ thickness and dewaxed. After rinsing with PBS, the slides were soaked in a solution containing $0.1 \%$ Triton X-100 and $0.1 \%$ sodium citrate for $2 \mathrm{~min}$ to increase the cell membrane permeability. The slides were incubated with $50 \mu 1$ of TUNEL reaction mixture for $60 \mathrm{~min}$ at $37^{\circ} \mathrm{C} .3,3^{\prime}$-Diaminobenzidine (DAB; $0.05 \%$ ) was added to the slide for $30 \mathrm{~min}$ and then incubated in the substrate solution (100 $\mu \mathrm{l}$ ) for an additional 10-15 min. Labeled myocytes were analyzed using a light microscope (XSZ-D2; Olympus Corporation).

Transmission electron microscopy. Heart samples were fixed with $2.5 \%$ glutaraldehyde for $24 \mathrm{~h}$ at $4{ }^{\circ} \mathrm{C}$, washed with PBS, and fixed with $1 \%$ osmium tetroxide for $2 \mathrm{~h}$. Samples were then dehydrated with fractionated acetone, embedded in Epon-Araldite resin, and cut into ultrathin sections of 50-70 nm. Ultrathin sections were placed on copper grids and stained with uranyl acetate and lead citrate. Samples were examined under a JEM-2000EX transmission electron microscope $(16,18)$. The images were captured using a Hamamatsu camera (Hamamatsu Photonics, Ltd.).

Western blot analysis. Protein extracts were prepared as aforementioned and subjected to 10\% SDS-PAGE. Each lane contained $60 \mu \mathrm{g}$ of protein. All samples were transferred to nitrocellulose membranes and blocked for $1 \mathrm{~h}$ at room temperature with 5\% BSA in Tris-buffered saline/Tween-20 (TBST) buffer. The membranes were then exposed to the rabbit monoclonal anti-rat CaSR antibody, the rabbit polyclonal serum 
against rat total PKC 8 , and GRP78, Calnexin, Caspase-12, p-JNK, JNK and Caspase-3 antibodies at a concentration of 1:1,000 overnight at $4^{\circ} \mathrm{C}$. The secondary antibody alkaline phosphatase IgG (1:2,000; cat. no. S3731; Promega Corporation) was then added for $2 \mathrm{~h}$ at room temperature. The final signals were quantified using a Bio-Rad Chemi Doc EQ densitometer and Bio-Rad Quantity One software (Bio-Rad Laboratories, Inc.). $\beta$-actin was used as internal reference for the total cytoplasmic extract. Calnexin was used as internal reference for the ER extract. All band intensities were normalized to $\beta$-actin or Calnexin and expressed as a percentage of the control sample.

Isolation of acute myocardial cells. Rats without any treatment were anesthetized with $2 \%$ pentobarbital $(100 \mathrm{mg} / \mathrm{kg}$, i.p.) and the hearts were quickly removed. Then the hearts were perfused $(5 \mathrm{~min})$ through the aorta with standard Tyrode's solution at $37^{\circ} \mathrm{C}$ until the residue was clear (19). The composition of the standard Tyrode's solution was: $136 \mathrm{mM} \mathrm{NaCl}$, $5.4 \mathrm{mM} \mathrm{KCl}, 0.35 \mathrm{mM} \mathrm{NaH}_{2} \mathrm{PO}_{4}, 1.0 \mathrm{mM} \mathrm{MgCl}, 2.0 \mathrm{mM}$ $\mathrm{CaCl}_{2}, 10 \mathrm{mM}$ dextrose and $10 \mathrm{mM}$ HEPES (pH adjusted to 7.4 with $\mathrm{NaOH}$ ). The solution was equilibrated with $95 \% \mathrm{O}_{2}$ and $5 \% \mathrm{CO}_{2}$ at room temperature prior to use. Then the hearts were sequentially perfused with $\mathrm{Ca}^{2+}$-free Tyrode's solution for $10 \mathrm{~min}$, and a $\mathrm{Ca}^{2+}$-free Tyrode's solution containing $0.015 \mathrm{~g} / \mathrm{l}$ collagenase for $30 \mathrm{~min}$. The ventricular tissue $(2-3 \mathrm{~mm}$ in diameter) was excised and placed in KB solution. The composition of the $\mathrm{KB}$ solution was: $70 \mathrm{mM}$ glutamic acid, $15 \mathrm{mM}$ taurin, $30 \mathrm{mM} \mathrm{KCl}, 10 \mathrm{mM} \mathrm{KH}_{2} \mathrm{PO}_{4}, 10 \mathrm{mM}$ HEPES, $0.5 \mathrm{mM} \mathrm{MgCl}_{2}, 0.5 \mathrm{mM}$ ethylene glycol tetraacetic acid and $10 \mathrm{mM}$ glucose (pH adjusted to 7.3-7.4 with $\mathrm{KOH}$ ). Myocardial cells were isolated and kept at room temperature (5).

The acutely isolated myocardial cells were then divided into five treatment groups: i) Control group, myocardial cells were incubated in Tyrode's solution without any treatment; ii) I/R group, myocardial cells were incubated with Tyrode's solution for $8 \mathrm{~min}$, then incubated in simulated ischemic solution $\left(\mathrm{NaCl} 136 \mathrm{mM}, \mathrm{KCl} 5.4 \mathrm{mM}, \mathrm{NaH}_{2} \mathrm{PO}_{4} 0.35 \mathrm{mM}, \mathrm{MgCl}_{2}\right.$ $1.0 \mathrm{mM}$ and Hepes $10 \mathrm{mM}, \mathrm{pH} 6.8$ ) at $37^{\circ} \mathrm{C}$ for $30 \mathrm{~min}$, and finally incubated with Tyrode's solution for another $8 \mathrm{~min}$; iii) $\mathrm{I} / \mathrm{R}+\mathrm{A}+\mathrm{V}+\mathrm{Gd}$, myocardial cells were incubated with simulated ischemia solution for $30 \mathrm{~min}$, followed by reperfusion for $8 \mathrm{~min}$ in Tyrode solution immediately after addition of $20 \mu \mathrm{M}$ Amiloride, $1 \mu \mathrm{M}$ Verapamil and $30 \mu \mathrm{M} \mathrm{GdCl}_{3}$; iv) $\mathrm{I} / \mathrm{R}+\mathrm{A}+\mathrm{V}+\mathrm{Gd}+\mathrm{NPS}, 20 \mu \mathrm{M}$ Amiloride, $1 \mu \mathrm{M}$ Verapamil, $30 \mu \mathrm{M} \mathrm{GdCl} 3$ and $10 \mu \mathrm{M}$ NPS-2390 were added to the myocardial cells before reperfusion with Tyrode's solution for $8 \mathrm{~min}$; and v) $\mathrm{I} / \mathrm{R}+\mathrm{A}+\mathrm{V}+\mathrm{Gd}+\mathrm{PKC} \mathrm{I}, 20 \mu \mathrm{M}$ Amiloride, $1 \mu \mathrm{M}$ Verapamil and $30 \mu \mathrm{M} \mathrm{GdCl}_{3}$ and $10 \mu \mathrm{M}$ Rottlerin were added to the myocardial cells before reperfusion with Tyrode's solution for $8 \mathrm{~min}$. Following treatments, cells were analyzed as indicated.

JC-1 fluorescence staining. The decrease of mitochondrial membrane potential is a landmark event in the early stages of apoptosis. This method can identify apoptotic cells earlier than other methods. Mitochondrial membrane potential was measured by JC-1 fluorescence staining. JC-1 is an ideal fluorescent probe for detecting mitochondrial membrane potential. When the mitochondrial membrane potential is high, JC-1 aggregates in the matrix of the mitochondria to form a polymer, which can produce red fluorescence. When the mitochondrial membrane potential is low, JC- 1 cannot accumulate in the matrix of mitochondria, and therefore JC-1 exists as a monomer which can produce green fluorescence. Therefore, changes in mitochondrial membrane potential can be easily detected through the change of fluorescence color. The relative ratio of green and red fluorescence is commonly used to measure the proportion of mitochondrial depolarization. The appearance of green fluorescence indicates a decrease in mitochondrial membrane potential, and the cell is likely to be in the early stages of apoptosis. Red fluorescence indicates that the mitochondrial membrane potential is normal and the state of the cells is normal.

In the present study, isolated cardiomyocytes were stained with JC-1 $(1 \mu \mathrm{g} / \mathrm{ml})$ for $15 \mathrm{~min}$ at $37^{\circ} \mathrm{C}$ and washed with Tyrode's solution three times. The changes of mitochondrial membrane potential were observed using confocal laser microscopy. The excitation light was set to $488 \mathrm{~nm}$ when the JC-1 monomer (green) was detected, and the emission light was set to $530 \mathrm{~nm}$. When the JC-1 polymer (red) was detected, the excitation light was set to $525 \mathrm{~nm}$, and the emission light was set to $590 \mathrm{~nm}$. Multiple fields of view ( $>10)$ were captured from each sample and the average intensity of each field was quantified. The intensity ratio of JC-1 polymer to JC-1 monomer in each field was calculated. A decrease of the ratio indicated a decrease in the membrane potential, and an increase of the ratio indicated an increase in the membrane potential.

Statistical analysis. Data were expressed as the mean \pm SD from three independent experiments. Data were analyzed using one-way ANOVA followed by Bonferroni post hoc tests. All statistical analyses were performed using Prism 5 (GraphPad Software, Inc.). P $<0.05$ was considered to indicate a statistically significant difference.

\section{Results}

CaSR involved in cardiomyocyte apoptosis during $I / R$. Previous studies have confirmed that myocardial I/R results in the translocation of PKC $\delta$ from the cell cytoplasm to the ER $(7,14,15)$, and activation of CaSR by myocardial I/R can induce cardiomyocyte apoptosis through the ER stress-related apoptosis pathway (6). However, the interaction of the CaSR with PKC $\delta$ to induce cardiomyocyte apoptosis in vivo has not been fully elucidated. Thus, the following experimental methods were used to confirm the relationship between CaSR and $\mathrm{PKC \delta}$ in cardiomyocyte apoptosis during $\mathrm{I} / \mathrm{R}$ in vivo.

Cardiomyocyte apoptosis was detected by TUNEL staining and JC-1 fluorescence staining. In the TUNEL experiment, normal cardiomyocyte nuclei were stained blue, while apoptotic cell nuclei were stained brown. The ratio of TUNEL-positive cells was increased significantly in the $\mathrm{I} / \mathrm{R}$ and $\mathrm{I} / \mathrm{R}+\mathrm{A}+\mathrm{V}+\mathrm{Gd}$ groups compared with the Control group $(\mathrm{P}<0.05$; Fig. 1$)$. In the $\mathrm{I} / \mathrm{R}+\mathrm{A}+\mathrm{V}+\mathrm{Gd}+\mathrm{NPS}$ group and $\mathrm{I} / \mathrm{R}+\mathrm{A}+\mathrm{V}+\mathrm{Gd}+\mathrm{PKC} \delta \mathrm{I}$ group, the ratio of apoptotic cells was lower compared with the $\mathrm{I} / \mathrm{R}+\mathrm{A}+\mathrm{V}+\mathrm{Gd}$ group $(\mathrm{P}<0.05$; Fig. 1$)$. The results of cardiomyocyte JC-1 staining revealed that the intensity ratio of JC-1 polymer/monomer decreased significantly in the $\mathrm{I} / \mathrm{R}$ and $\mathrm{I} / \mathrm{R}+\mathrm{A}+\mathrm{V}+\mathrm{Gd}$ groups compared with 


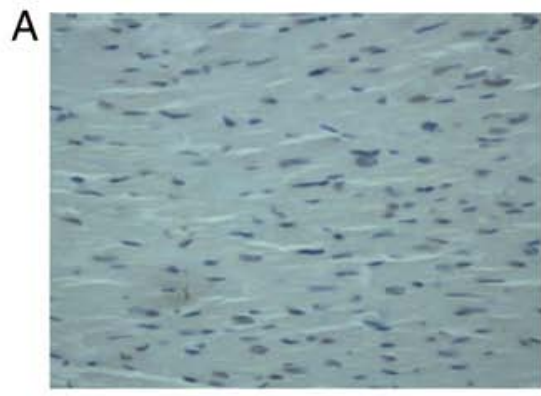

Control

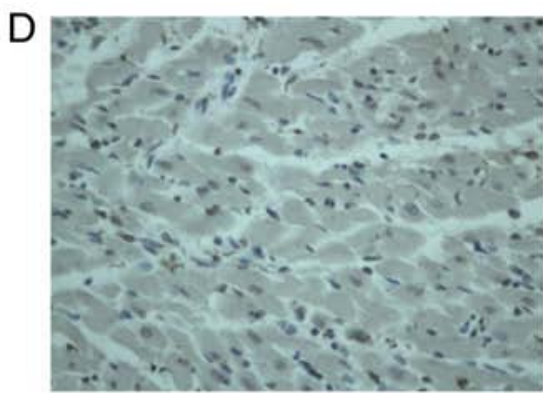

$\mathrm{I} / \mathrm{R}+\mathrm{A}+\mathrm{V}+\mathrm{Gd}$

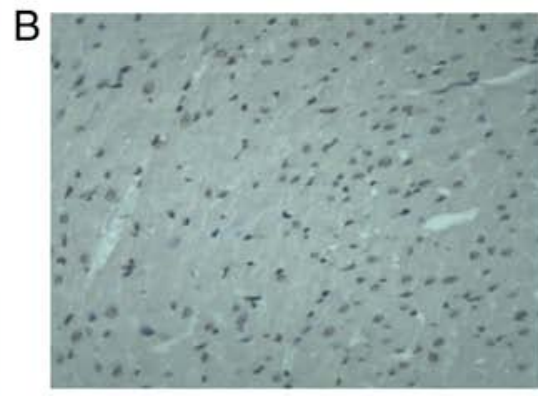

I/R

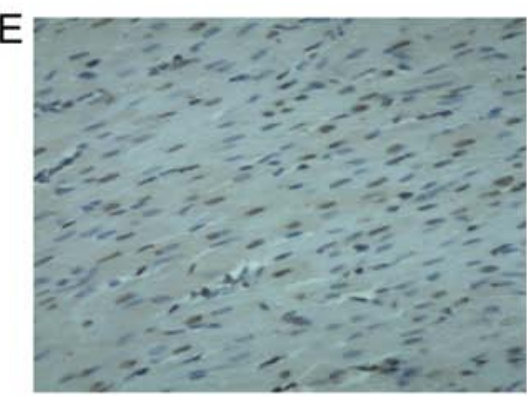

$\mathrm{I} / \mathrm{R}+\mathrm{A}+\mathrm{V}+\mathrm{Gd}+\mathrm{PKC} \delta$

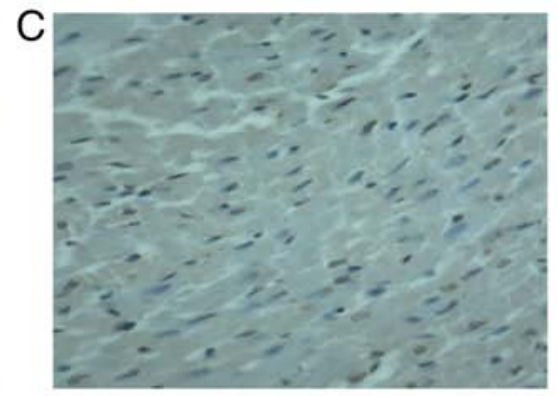

$\mathrm{I} / \mathrm{R}+\mathrm{A}+\mathrm{V}+\mathrm{Gd}+\mathrm{NPS}$

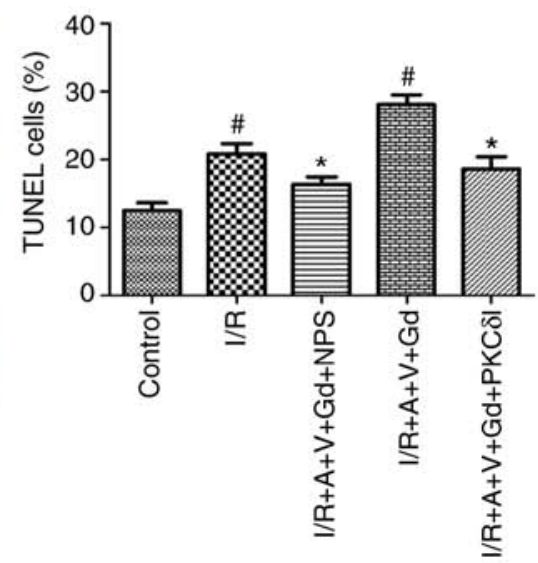

Figure 1. Representative images from TUNEL staining of cardiomyocytes following I/R. Nuclei with brown staining indicate TUNEL-positive cells. (A) Control group, (B) I/R group, (C) I/R+Amiloride+Verapamil $+\mathrm{GdCl}_{3}+\mathrm{NPS}-2390$ (I/R+A+V+Gd+NPS) group, (D) I/R+Amiloride+Verapamil+GdCl 3 $\left(\mathrm{I} / \mathrm{R}+\mathrm{A}+\mathrm{V}+\mathrm{Gd}\right.$ ) group and (E) $\mathrm{I} / \mathrm{R}+\mathrm{Amiloride}+$ Verapamil $+\mathrm{GdCl}_{3}+\mathrm{Rottlerin}(\mathrm{I} / \mathrm{R}+\mathrm{A}+\mathrm{V}+\mathrm{Gd}+\mathrm{PKC} \mathrm{I})$ group (magnification, $\left.\mathrm{x} 200\right)$. Quantitative results of TUNEL staining for different groups is shown in the lower panel. Values represent means $\pm \mathrm{SEM}(\mathrm{n}=7)$. ${ }^{*} \mathrm{P}<0.05 \mathrm{vs}$. Control group; ${ }^{*} \mathrm{P}<0.05 \mathrm{vs}$. $\mathrm{I} / \mathrm{R}+\mathrm{A}+\mathrm{V}+\mathrm{Gd}$ group. I/R, ischemia/reperfusion.

the Control group ( $\mathrm{P}<0.05$; Fig. 2). However, compared with the $\mathrm{I} / \mathrm{R}+\mathrm{A}+\mathrm{V}+\mathrm{Gd}$ group, the ratio of JC-1 polymer/monomer in the $\mathrm{I} / \mathrm{R}+\mathrm{A}+\mathrm{V}+\mathrm{Gd}+\mathrm{NPS}$ and $\mathrm{I} / \mathrm{R}+\mathrm{A}+\mathrm{V}+\mathrm{Gd}+\mathrm{PKC} \mathrm{I}$ groups remained at a high level $(\mathrm{P}<0.05$; Fig. 2$)$.

Morphological characterization of cardiomyocyte apoptosis. In the present study, ultrastructural changes in cardiomyocytes were examined by transmission electron microscopy. Morphological characteristics indicating apoptosis include condensation, aggregation and margination of nuclear chromatin, ER expansion, capsule bubble and mitochondrial swelling, and mitochondrial crest fracture. These apoptotic characteristics were observed in the $\mathrm{I} / \mathrm{R}+\mathrm{A}+\mathrm{V}+\mathrm{Gd}$ and $\mathrm{I} / \mathrm{R}$ groups, but not in the Control group (Fig. 3). By contrast, in the $\mathrm{I} / \mathrm{R}+\mathrm{A}+\mathrm{V}+\mathrm{Gd}+\mathrm{NPS}$ and $\mathrm{I} / \mathrm{R}+\mathrm{A}+\mathrm{V}+\mathrm{Gd}+\mathrm{PKC} \mathrm{I}$ groups, only a slight margination of the nuclear chromatin, expansion of the ER and swelling of the mitochondrion were observed (Fig. 3).

CaSR protein expression in myocardial cells. Since CaSR serves a key role in the elevation of $\left[\mathrm{Ca}^{2+}\right]$ i in cardiomyocytes (5), the expression levels of the CaSR protein, with a relative molecular mass of $130 \mathrm{kDa}$, were determined by western blot analysis. Compared with the Control group, the protein expression levels of CaSR in the I/R and I/R+A+V+Gd groups were increased ( $\mathrm{P}<0.05$; Fig. 4). Additionally, the CaSR protein expression levels in the $\mathrm{I} / \mathrm{R}+\mathrm{A}+\mathrm{V}+\mathrm{Gd}+\mathrm{NPS}$ group was decreased compared with the $\mathrm{I} / \mathrm{R}+\mathrm{A}+\mathrm{V}+\mathrm{Gd}$ group $(\mathrm{P}<0.05$; Fig. 4). These results demonstrated that $\mathrm{GdCl}_{3}$ could upregulate the expression of CaSR (Fig. 4).

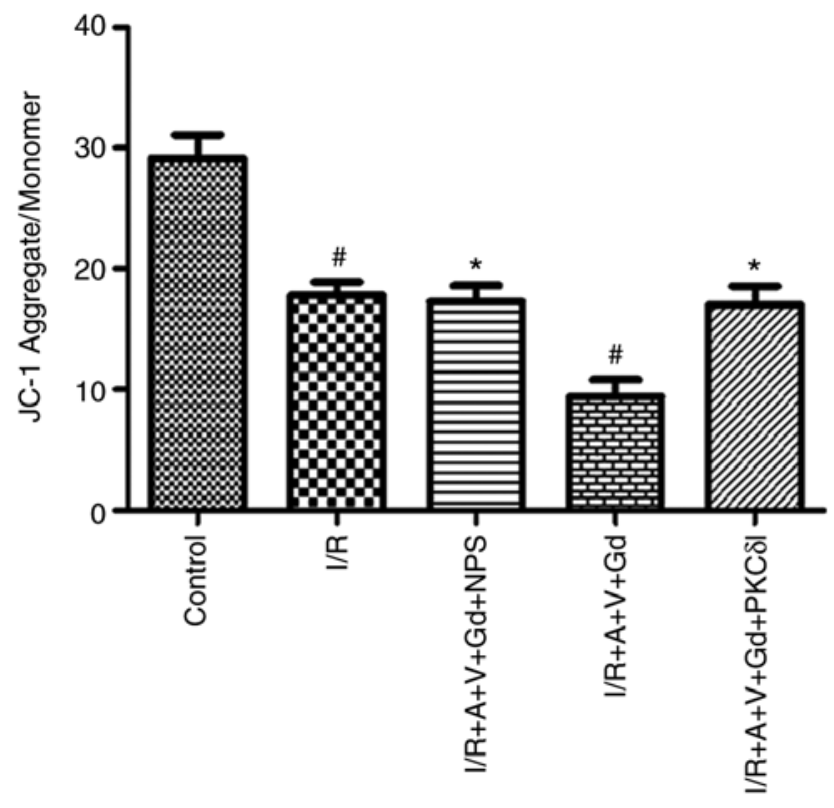

Figure 2. Relative changes in JC-1 fluorescence intensity of cardiomyocytes following I/R. The fluorescence intensity ratio of JC-1 in its aggregate and monomer forms was calculated in the different groups. Values represent means $\pm \operatorname{SEM}(\mathrm{n}=6) .{ }^{\sharp} \mathrm{P}<0.05$ vs. Control group; ${ }^{*} \mathrm{P}<0.05$ vs. $\mathrm{I} / \mathrm{R}+\mathrm{A}+\mathrm{V}+\mathrm{Gd}$ group. JC-1, 5,5',6,6'-Tetrachloro-1,1',3,3'-tetraethylbenzimidazolocarbocyanine iodide; $\mathrm{I} / \mathrm{R}$, ischemia/reperfusion.

Effect of CaSR in myocardial $I / R$ on the expression of ER stress-related proteins in vivo. The ER environment can 


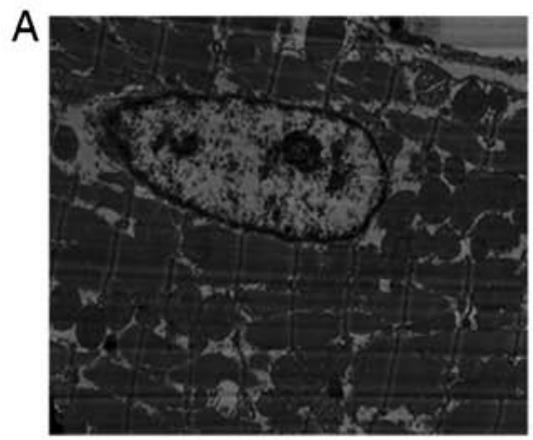

Control

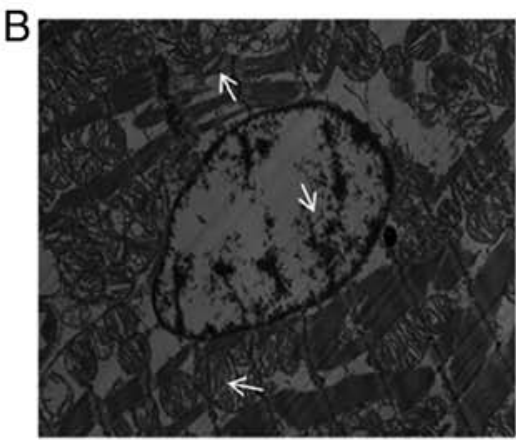

I/R

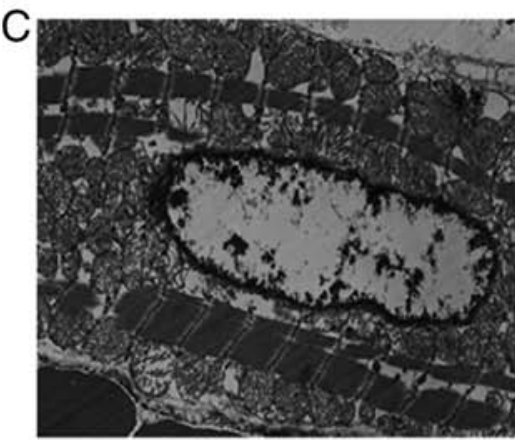

$\mathrm{l} / \mathrm{R}+\mathrm{A}+\mathrm{V}+\mathrm{Gd}+\mathrm{NPS}$

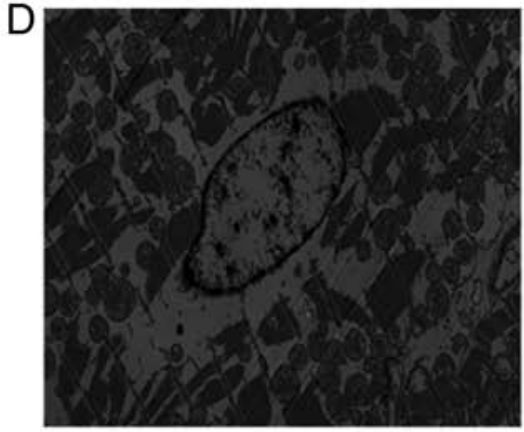

$\mathrm{I} / \mathrm{R}+\mathrm{A}+\mathrm{V}+\mathrm{Gd}$

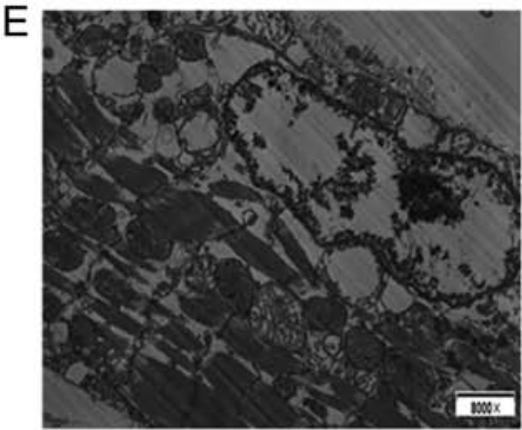

$\mathrm{I} / \mathrm{R}+\mathrm{A}+\mathrm{V}+\mathrm{Gd}+\mathrm{PKC} \delta$

Figure 3. Transmission electron micrographs of cardiac tissue ultrastructure changes. (A) Control group, (B) I/R group, (C) $I / R+A+V+G d+N P S$ group, (D) $\mathrm{I} / \mathrm{R}+\mathrm{A}+\mathrm{V}+\mathrm{Gd}$ group and (E) $\mathrm{I} / \mathrm{R}+\mathrm{A}+\mathrm{V}+\mathrm{Gd}+\mathrm{PKC} \mathrm{I}$ group (magnification, $\mathrm{x} 8,000$ ). $\mathrm{I} / \mathrm{R}$, ischemia/reperfusion

CasR

$\beta$-actin

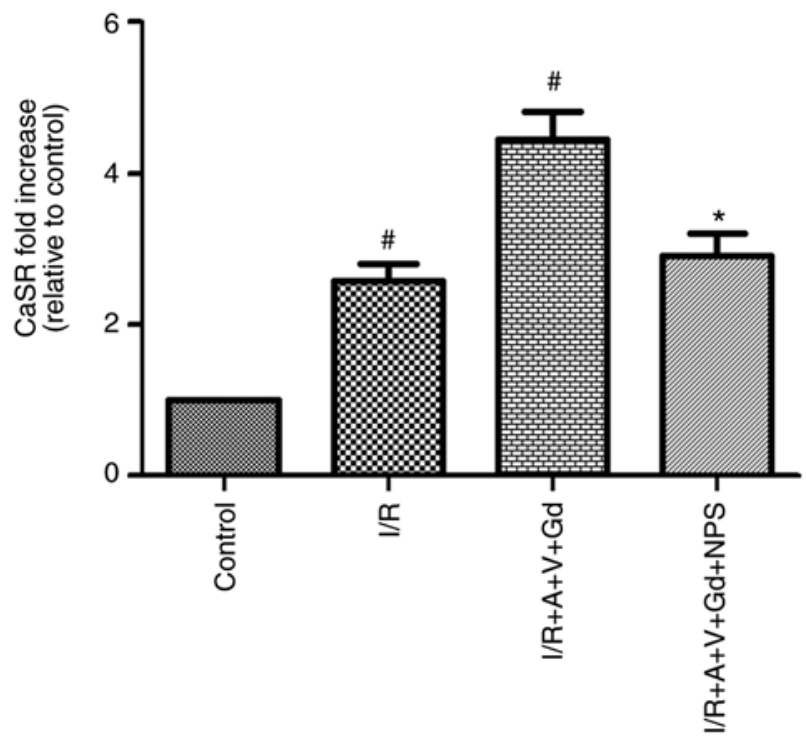

Figure 4. Western blot analysis for CaSR in rat cardiomyocytes of different groups. Representative blots and quantification of CaSR expression levels relative to the Control group are shown. Values represent means \pm SEM ( $\mathrm{n}=3-4) .{ }^{~} \mathrm{P}<0.05$ vs. Control group; ${ }^{*} \mathrm{P}<0.05$ vs. $\mathrm{I} / \mathrm{R}+\mathrm{A}+\mathrm{V}+\mathrm{Gd}$ group. $\mathrm{CaSR}$, calcium-sensing receptor; I/R, ischemia/reperfusion.

be stimulated by various stimuli, such as a perturbation of $\mathrm{Ca}^{2+}$ homeostasis, which leads to initiation of the unfolded protein response (UPR). The UPR is a protective mechanism against ER stress, which is conducive to the stability of the cellular environment. If excessive ER stress is not resolved, it will induce cell apoptosis (20). To detect the occurrence of ER stress, protein expression levels of ER stress-related proteins, such as GRP78, can be detected, which is resistant to the UPR and has been extensively used as a marker for ER stress and UPR (21). In the present study, the protein expression levels of GRP78 were detected by western blot analysis. The results demonstrated that GRP78 expression in the I/R and $\mathrm{I} / \mathrm{R}+\mathrm{A}+\mathrm{V}+\mathrm{Gd}$ groups was significantly higher compared with the Control group, but in the $\mathrm{I} / \mathrm{R}+\mathrm{A}+\mathrm{V}+\mathrm{Gd}+\mathrm{NPS}$ and $\mathrm{I} / \mathrm{R}+\mathrm{A}+\mathrm{V}+\mathrm{Gd}+\mathrm{PKC} \delta \mathrm{I}$ groups, GRP78 expression was significantly lower compared with the $\mathrm{I} / \mathrm{R}+\mathrm{A}+\mathrm{V}+\mathrm{Gd}$ group $(\mathrm{P}<0.05$; Fig. 5). The present results demonstrated that activated CaSR in I/R induced ER stress in vivo. These results also determined that inhibition of PKC $\delta$ may protect the myocardium from ER stress in an in vivo model of I/R myocardial injury.

CaSR activates PKCD induction of the ER stress-induced apoptosis pathway in vivo. The translocation of PKCD to the ER, to participate in ER stress-induced apoptosis, has been previously documented (14). Next, the present study investigated whether CaSR activating PKC $\delta$ participated in the apoptotic pathway in vivo. Previous studies have shown that several molecules, including JNK, CCAAT/enhancer-binding protein-homologous protein (CHOP) and Caspase-12, are involved in the ER stress-induced apoptosis pathway (22). In the current study, the protein expression of Caspase-12, p-JNK and Caspase- 3 in cardiomyocytes was examined by western blot analysis. Cleaved Caspase-12 (the $42 \mathrm{kDa}$ proteolytic fragment of Caspase-12) was significantly increased in the 
GRP78

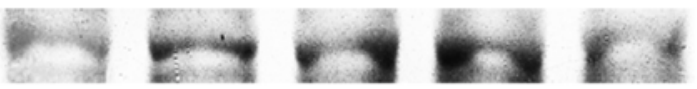

$\beta$-actin

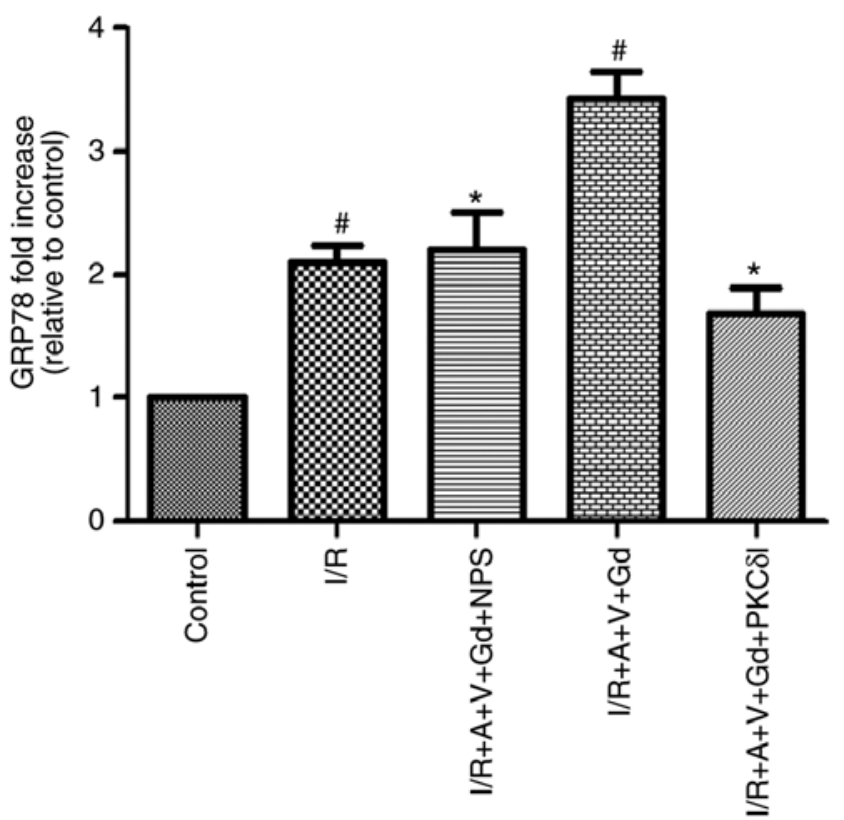

Figure 5. Western blot analysis for GRP78 in rat cardiomyocytes by activating CaSR. Representative blots and quantification of GRP78 expression levels relative to the Control group are shown. Values represent means \pm SEM ( $\mathrm{n}=3-4) .{ }^{\#} \mathrm{P}<0.05$ vs. Control group; ${ }^{*} \mathrm{P}<0.05$ vs. $\mathrm{I} / \mathrm{R}+\mathrm{A}+\mathrm{V}+\mathrm{Gd}$ group. GRP78, glucose-regulated protein $78 ; \mathrm{I} / \mathrm{R}$, ischemia/reperfusion.

$\mathrm{I} / \mathrm{R}$ and $\mathrm{I} / \mathrm{R}+\mathrm{A}+\mathrm{V}+\mathrm{Gd}$ groups compared with the Control group $(\mathrm{P}<0.05$; Fig. 6$)$. The expression levels of cleaved Caspase 12 were decreased in the $\mathrm{I} / \mathrm{R}+\mathrm{A}+\mathrm{V}+\mathrm{Gd}+\mathrm{NPS}$ and $\mathrm{I} / \mathrm{R}+\mathrm{A}+\mathrm{V}+\mathrm{Gd}+\mathrm{PKC}$ I groups compared with the $\mathrm{I} / \mathrm{R}+\mathrm{A}+\mathrm{V}+\mathrm{Gd}$ group $(\mathrm{P}<0.05$, Fig. 6). As presented in Fig. 7 , the protein expression levels of Caspase- 3 and the ratio of $\mathrm{p}-\mathrm{JNK} / \mathrm{JNK}$ in the $\mathrm{I} / \mathrm{R}$ and $\mathrm{I} / \mathrm{R}+\mathrm{A}+\mathrm{V}+\mathrm{Gd}$ groups were higher compared with the Control group. The levels of Caspase-3 and the p-JNK/JNK ration in the $\mathrm{I} / \mathrm{R}+\mathrm{A}+\mathrm{V}+\mathrm{Gd}+\mathrm{NPS}$ and $\mathrm{I} / \mathrm{R}+\mathrm{A}+\mathrm{V}+\mathrm{Gd}+\mathrm{PKC} \delta \mathrm{I}$ groups were decreased compared wih the $\mathrm{I} / \mathrm{R}+\mathrm{A}+\mathrm{V}+\mathrm{Gd}$ group $(\mathrm{P}<0.05$; Fig. 7). The protein expression levels of Caspase-12, p-JNK and Caspase- 3 are related to the rate of apoptosis of cardiomyocytes. Therefore, the present results revealed that CaSR activated PKC $\delta$ to participate in apoptosis through the ER stress-induced apoptosis pathway.

CaSR induces PKC $\delta$ translocation to the ER following $I / R$ and participates in the ER stress-induced apoptosis pathway. In the myocardium, inhibition of PKC $\delta$ activation could significantly inhibit the ER stress response at the beginning of reperfusion (14). In the present study, expression of total-PKC $\delta$ in the cytoplasm of myocardial cells was detected by western blotting in each group (Fig. 8A). In the $\mathrm{I} / \mathrm{R}, \mathrm{I} / \mathrm{R}+\mathrm{A}+\mathrm{V}+\mathrm{Gd}$, $\mathrm{I} / \mathrm{R}+\mathrm{A}+\mathrm{V}+\mathrm{Gd}+\mathrm{NPS}$ and $\mathrm{I} / \mathrm{R}+\mathrm{A}+\mathrm{V}+\mathrm{Gd}+\mathrm{PKC} \delta \mathrm{I}$ groups, total-PKC $\delta$ protein expression levels were significantly higher compared with the Control group ( $\mathrm{P}<0.05 ;$ Fig. 8A). The present study also quantitatively analyzed the expression of PKC $\delta$ in the ER fractions (Fig. 8B). The PKC 8 expression levels of
Caspase-12

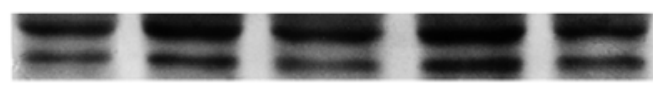

$\beta$-actin
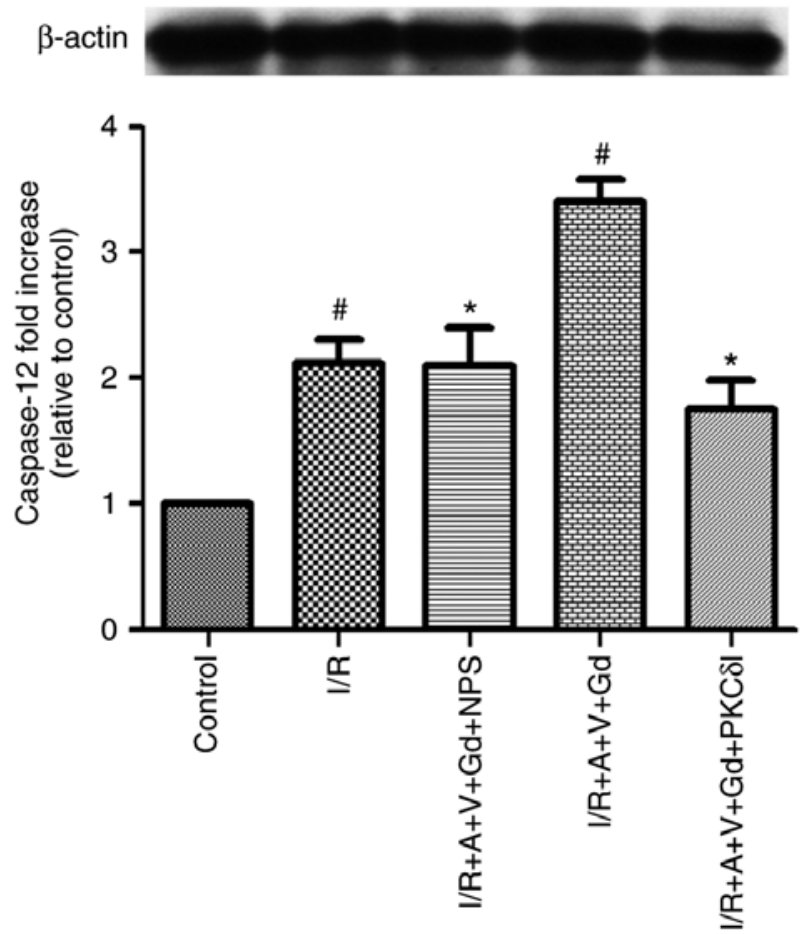

Figure 6. Western blot analysis for activated Caspase-12 in rat cardiomyocytes. Representative blots and quantification of cleaved Caspace-12 expression levels relative to the Control group are shown. Values are expressed as mean \pm SEM $(n=3-4)$. ${ }^{\#} \mathrm{P}<0.05$ vs. sham Control group; ${ }^{*} \mathrm{P}<0.05$ vs. I/R+A+V+Gd group. I/R, ischemia/reperfusion.

the $\mathrm{I} / \mathrm{R}$ and $\mathrm{I} / \mathrm{R}+\mathrm{A}+\mathrm{V}+\mathrm{Gd}$ groups were significantly higher compared with the Control group $(\mathrm{P}<0.05$; Fig. $8 \mathrm{~B})$, while the levels of PKC $\delta$ from the ER fractions were significantly inhibited in the $\mathrm{I} / \mathrm{R}+\mathrm{A}+\mathrm{V}+\mathrm{Gd}+\mathrm{NPS}$ and $\mathrm{I} / \mathrm{R}+\mathrm{A}+\mathrm{V}+\mathrm{Gd}+\mathrm{PKC} \mathrm{I}$ groups compared with the $\mathrm{I} / \mathrm{R}+\mathrm{A}+\mathrm{V}+\mathrm{Gd}$ group $(\mathrm{P}<0.05$; Fig. 8B). These results demonstrated that CaSR induced $\mathrm{PKC} \delta$ translocation to the ER following $\mathrm{I} / \mathrm{R}$ and participated in the ER stress-induced apoptosis pathway.

\section{Discussion}

The results of the present study confirmed that the activation of CaSR induced PKC $\delta$ translocation to the ER following $\mathrm{I} / \mathrm{R}$ and participated in cardiomyocyte apoptosis via the ER stress-associated apoptotic pathway in vivo.

It is well-established that $\mathrm{I} / \mathrm{R}$ injury can lead to activation of PKC. PKC, as a kind of $\mathrm{Ca}^{2+}$ and phospholipid-dependent protein kinase, is involved in the apoptosis of cardiac muscle cells by regulating $\left[\mathrm{Ca}^{2+}\right]$ i homeostasis. The PKC family contains 13 subtypes, and the PKCE and PKC 8 subtypes have been well-studied. The former mainly serevs a role in the inhibition of apoptosis, while the latter mainly acts in the promotion of apoptosis. CaSR acts as a protein-coupled receptor, causing the accumulation of inositol phosphate (IP), which leads to an increase in intracellular calcium. However, the PKC $\delta$ inhibitor, rottlerin, can reverse the occurrence of this phenomenon by inhibiting CaSR $(5,23)$. The links between $\mathrm{PKC} \delta, \mathrm{CaSR}$ and ER stress during I/R remain unclear. To 

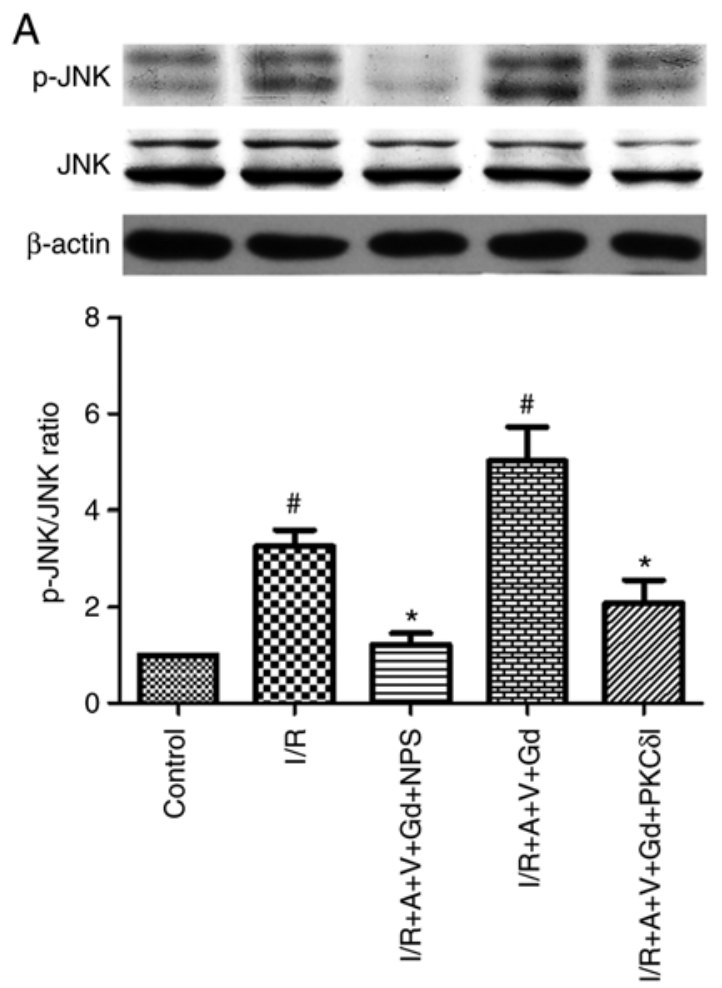

B
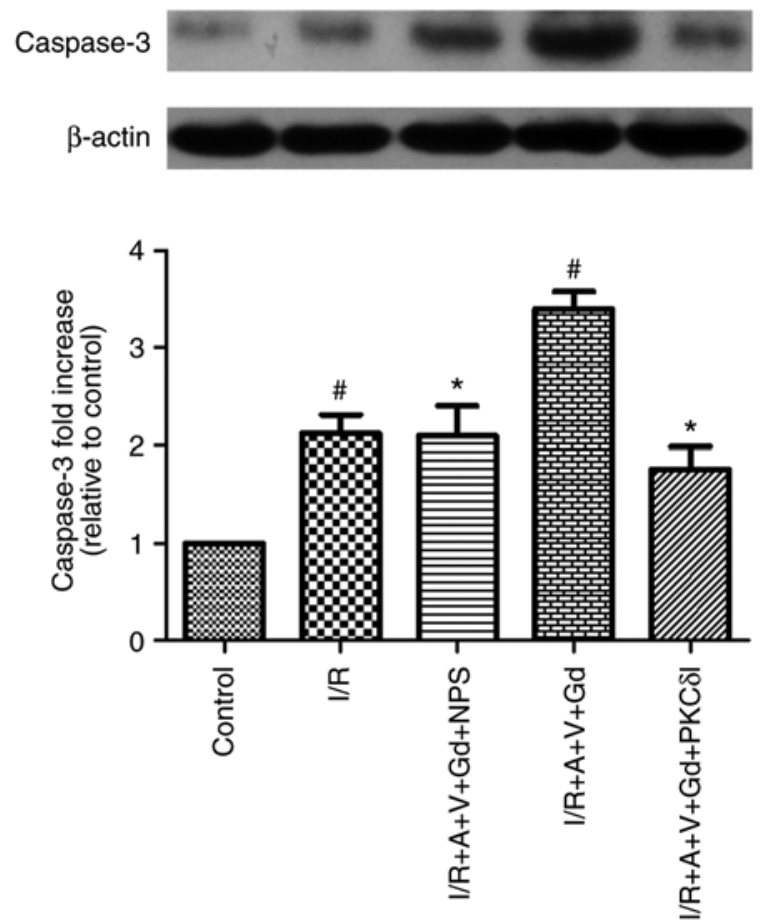

Figure 7. Western blot analysis for JNK activation and Caspase-3 expression in rat cardiomyocytes following I/R. (A) Representative blots and quantification of p-JNK and total JNK. (B) Representative blots and quantification of Caspase-3 protein expression levels. All values are plotted as relative to the Control group and as means $\pm \operatorname{SEM}(\mathrm{n}=3-4)$. ${ }^{\#} \mathrm{P}<0.05$ vs. Control group; ${ }^{*} \mathrm{P}<0.05$ vs. $\mathrm{I} / \mathrm{R}+\mathrm{A}+\mathrm{V}+\mathrm{Gd}$ group. $\mathrm{I} / \mathrm{R}$, ischemia/reperfusion; $\mathrm{p}-$, phosphorylated.

A
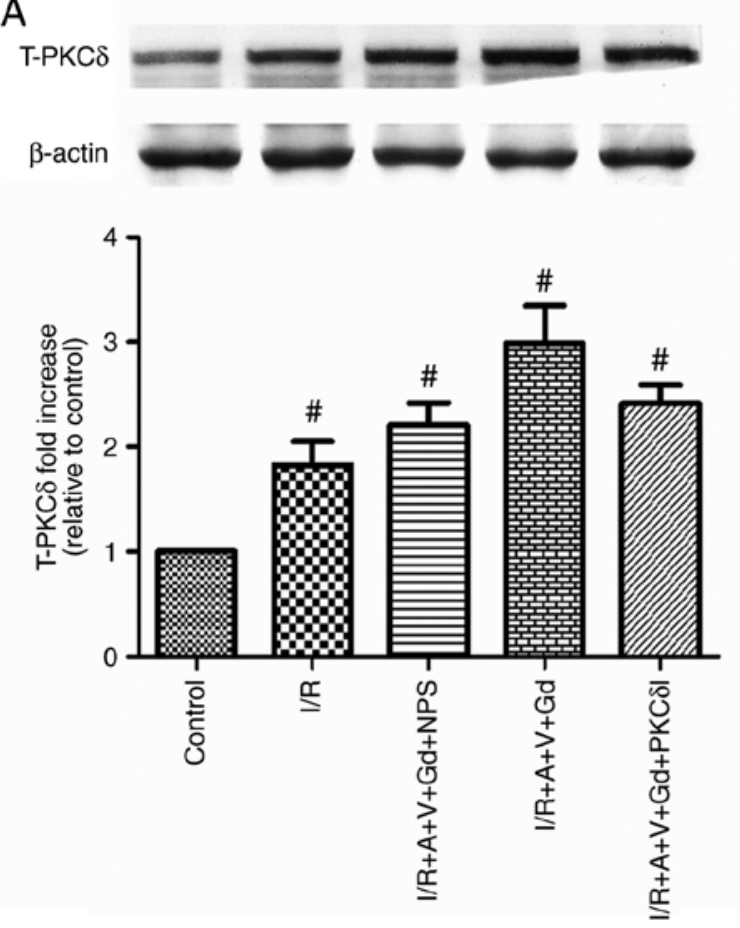

B
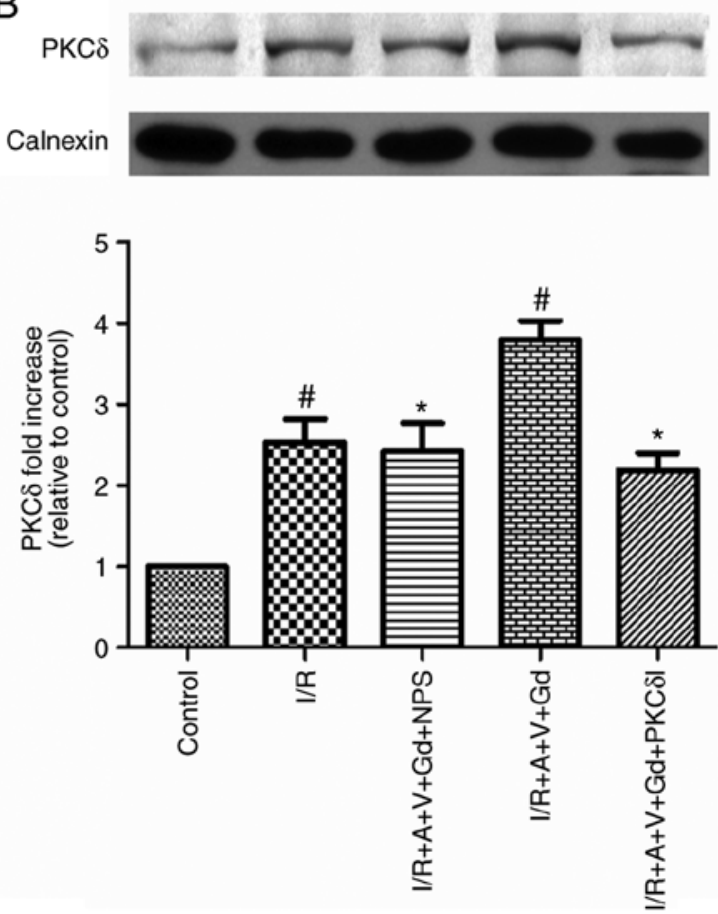

Figure 8. Protein expression of PKC $\delta$ in the total cytoplasm and in ER fractions of rat cardiac tissue following I/R. (A) Levels of total-PKC in the cytoplasm and (B) in ER-specific fractions in cardiomyocytes from the experimental groups. Values are plotted as relative to the Control group and as means \pm SEM $(\mathrm{n}=3-4) .{ }^{*} \mathrm{P}<0.05$ vs. Control group; ${ }^{*} \mathrm{P}<0.05$. vs. I/R+A+V+Gd group. $\mathrm{PKC} \delta$, protein kinase $\mathrm{C} \delta$; ER, endoplasmic reticulum; I/R, ischemia/reperfusion.

investigate the effect of activation of PKC $\delta$ by CaSR on myocardial I/R, $\mathrm{GdCl}_{3}$ (an activator of CaSR), NPS-2390 (an inhibitor of CaSR), amiloride (an inhibitor of the $\mathrm{Na}^{+}-\mathrm{Ca}^{2+}$ exchanger), verapamil (an L-type calcium channel blocker) and rottlerin (a PKC $\delta$ inhibitor) were used in the present study. The experimental animals were divided into five 
groups: Control, $\mathrm{I} / \mathrm{R}, \mathrm{I} / \mathrm{R}+\mathrm{A}+\mathrm{V}+\mathrm{Gd}, \mathrm{I} / \mathrm{R}+\mathrm{A}+\mathrm{V}+\mathrm{Gd}+\mathrm{NPS}$ and $\mathrm{I} / \mathrm{R}+\mathrm{A}+\mathrm{V}+\mathrm{Gd}+\mathrm{PKC} \delta \mathrm{I}$ groups.

First, the expression of CaSR in myocardial I/R was detected by western blot analysis. CaSR, also known as the parathyroid cell CaSR, is an integral membrane protein belonging to the G-protein coupled receptor 3 family. The molecular weights of CaSR are 110, 130 and $150 \mathrm{kDa}$, of which the $150 \mathrm{kDa}$ form is the mature form of CaSR. CaSR is present on the cell membrane. In the present study, the $130 \mathrm{kDa}$ CaSR protein was detected in the cardiac tissues. Compared with the Control group, the expression of CaSR in the $\mathrm{I} / \mathrm{R}$ and $\mathrm{I} / \mathrm{R}+\mathrm{A}+\mathrm{V}+\mathrm{Gd}$ groups increased. However, in the $\mathrm{I} / \mathrm{R}+\mathrm{A}+\mathrm{V}+\mathrm{Gd}+\mathrm{NPS}$ group, the CaSR protein expression levels was lower compared with the $\mathrm{I} / \mathrm{R}+\mathrm{A}+\mathrm{V}+\mathrm{Gd}$ group. Thus, $\mathrm{I} / \mathrm{R}$ and $\mathrm{GdCl}_{3}$ were demonstrated to increase CaSR expression.

Multiple studies have indicated that PKC can regulate the intracellular $\mathrm{Ca}^{2+}$ concentration $(24,25)$ and participate in the protection or damage of cardiac muscle cells by CaSR-mediated intracellular calcium release. In the present study, cardiomyocyte apoptosis was examined by JC-1 fluorescence staining and TUNEL staining. The decrease of mitochondrial membrane potential is a landmark event in the early stages of apoptosis. JC-1 is an ideal fluorescent probe for detecting mitochondrial membrane potential. Therefore, the JC-1 method was used to detect early apoptosis following myocardial I/R. The sensitivity of the TUNEL method for detecting apoptosis is very high, and it is also possible to quantitatively analyze apoptotic cells of both the middle or late stages. The results of cardiomyocyte JC-1 straining analysis revealed that the intensity ratio of JC-1 polymer/monomer decreased significantly in the I/R and $\mathrm{I} / \mathrm{R}+\mathrm{A}+\mathrm{V}+\mathrm{Gd}$ groups compared with the Control group. Similarly, the ratio of TUNEL-positive cells was significantly higher in the I/R and $\mathrm{I} / \mathrm{R}+\mathrm{A}+\mathrm{V}+\mathrm{Gd}$ groups compared with the Control group. In addition, the ultrastructural changes of the myocardial cells were observed by transmission electron microscopy. In the $\mathrm{I} / \mathrm{R}$ and $\mathrm{I} / \mathrm{R}+\mathrm{A}+\mathrm{V}+\mathrm{Gd}$ groups, the myocardial cell structure was disordered, and the nuclear chromatin was condensed and concentrated. By contrast, in the $\mathrm{I} / \mathrm{R}+\mathrm{A}+\mathrm{V}+\mathrm{Gd}+\mathrm{NPS}$ and $\mathrm{I} / \mathrm{R}+\mathrm{A}+\mathrm{V}+\mathrm{Gd}+\mathrm{PKC} \mathrm{I}$ groups, only a slight margination of the nuclear chromatin, expansion of the ER and swelling of the mitochondrion were observed. Based on the aforementioned results, the experiments revealed that $\mathrm{GdCl}_{3}$ significantly increased the occurrence of cardiomyocyte apoptosis following I/R. The data also demonstrated that inhibition of PKC $\delta$ or CaSR significantly reduced the rate of cardiomyocyte apoptosis and protected cardiomyocytes from myocardial I/R injury.

The ER environment can be impaired by various stimuli, such as a perturbation of $\mathrm{Ca}^{2+}$ homeostasis, which leads to the UPR. Excessive UPR can stimulate ER stress (20). Previous studies have demonstrated that CaSR-induced $\mathrm{Ca}^{2+}$ release from internal stores is a PLC-mediated/IP3-dependent process. The enhancement of $\left[\mathrm{Ca}^{2+}\right] \mathrm{i}$ may be related to the release of $\mathrm{Ca}^{2+}$ by the ER $(6,26)$. To examine the occurrence of ER stress, the protein levels of GRP78 were detected. GRP78 is an ER molecular chaperone protein that promotes protein folding and the internal environment of calcium ions, protecting cells against oxidative stress and apoptosis, and has been extensively used as a marker for ER stress and the onset of the UPR $(21,27)$. Protein expression of GRP78 can thus be used as a marker of ER stress (28-30). In the present study, the expression of GRP78 was detected by western blot analysis. The results demonstrated that GRP78 protein expression levels in the $\mathrm{I} / \mathrm{R}$ and $\mathrm{I} / \mathrm{R}+\mathrm{A}+\mathrm{V}+\mathrm{Gd}$ groups were significantly higher compared with the Control group; however, the levels of the $\mathrm{I} / \mathrm{R}+\mathrm{A}+\mathrm{V}+\mathrm{Gd}+\mathrm{NPS}$ and $\mathrm{I} / \mathrm{R}+\mathrm{A}+\mathrm{V}+\mathrm{Gd}+\mathrm{PKC} \delta \mathrm{I}$ groups were decreased compared with the $\mathrm{I} / \mathrm{R}+\mathrm{A}+\mathrm{V}+\mathrm{Gd}$ group. Based on the present results, activated CaSR in $\mathrm{I} / \mathrm{R}$ was demonstrated to induce ER stress in vivo. These data also determined that inhibition of PKC 8 may protect the myocardium from ER stress in an in vivo model of I/R injury.

Next, the current study investigated whether activation of PKC $\delta$ by CaSR participated in ER stress-initiated apoptotic signaling. Studies have confirmed that several molecules, including Caspase-12, CHOP and JNK, are involved in the ER stress-induced apoptosis pathway (22). Caspase-12, an ER membrane-resident apoptotic molecule, can lead to cardiomyocyte apoptosis and cardiac dysfunction $(31,32)$. The JNK signaling pathway is one of the important mitogen-activated protein kinase pathways, and serves an important regulatory role in a variety of physiological and pathological programmed cell death processes (33). Both in vitro and in vivo experiments have demonstrated that high-intensity ER overstress activates inositol dependent enzyme 1 (IRE1) and its downstream tumor necrosis factor receptor-associated factor 2 (TRAF2)/apoptosis signal-regulated kinase (ASK1)/JNK apoptotic signaling pathway $(34,35)$. JNK exerts its pro-apoptotic effect by activating the downstream caspase-9 and caspase-3 (36). In the present study, the protein expression levels of Caspase-12, p-JNK and Caspase-3 in cardiomyocytes were measured by western blot analysis. The results demonstrated that the activation of Caspase-12, p-JNK and Caspase-3 were significantly higher following $\mathrm{I} / \mathrm{R}$ injury. Therefore, CaSR-activated PKC $\delta$ induced endoplasmic reticulum $\mathrm{Ca}^{2+}$ depletion and activated the ER stress-associated pathway to participate in the process of cardiomyocyte apoptosis during I/R injury.

Several studies have indicated that inhibition of PKCD activation could significantly inhibit the ER stress response at the beginning of reperfusion in the myocardium (14). In the present study, the expression of total-PKC $\delta$ in the cytoplasm of myocardial cells was detected by western blotting. Compared with the Control group, the expression levels of total-PKC $\delta$ protein in the $I / R, I / R+A+V+G d$, $\mathrm{I} / \mathrm{R}+\mathrm{A}+\mathrm{V}+\mathrm{Gd}+\mathrm{NPS}$ and $\mathrm{I} / \mathrm{R}+\mathrm{A}+\mathrm{V}+\mathrm{Gd}+\mathrm{PKC} \mathrm{I}$ groups were significantly increased. Expression of $\mathrm{PKC} \delta$ was also quantitatively analyzed in the ER fractions. The levels of PKC $\delta$ in the $I / R$ and $I / R+A+V+G d$ groups were significantly higher compared with the Control group, while the levels of PKC $\delta$ in the ER fractions was significantly lower in the $\mathrm{I} / \mathrm{R}+\mathrm{A}+\mathrm{V}+\mathrm{Gd}+\mathrm{NPS}$ and $\mathrm{I} / \mathrm{R}+\mathrm{A}+\mathrm{V}+\mathrm{Gd}+\mathrm{PKC} \delta \mathrm{I}$ groups compared with the $\mathrm{I} / \mathrm{R}+\mathrm{A}+\mathrm{V}+\mathrm{Gd}$ group. These results revealed that CaSR induced PKC 8 translocation to the ER, which then participated in cardiomyocyte apoptosis via ER stress-associated pathways.

In summary, the present results confirmed that activation of CaSR induced the translocation of PKC $\delta$ to the ER following $\mathrm{I} / \mathrm{R}$ and participated in cardiomyocyte apoptosis via ER stress-associated apoptotic pathways in vivo. 


\section{Acknowledgements}

Not applicable.

\section{Funding}

The present study was funded by the National Natural Science Foundation of China (grant nos. 81670344, 81370421 and 81370330), the Natural Science Foundation of Heilongjiang (grant no. D201070) and the High-Priority Health Projects of Tianjin (grant no. 16KG146).

\section{Availability of data and materials}

The datasets used and/or analyzed during the present study are available from the corresponding author on reasonable request.

\section{Authors' contributions}

WZ conceived and designed the experiments. CL, MZ, HZ, TF, FL, HL and SD performed the experiments and analyzed the data. CL and HL wrote the paper. HZ, MZ and HL contributed to the manuscript revisions. All authors read and approved the final manuscript.

\section{Ethics approval and consent to participate}

The present study was approved by the Ethics Committee of Basic Medical College of Harbin Medical University [permit no. SCXK (Hei) 2013-001].

\section{Patient consent for publication}

Not applicable.

\section{Competing interests}

The authors declare that they have no competing interests.

\section{References}

1. Wang R, Xu C, Zhao W, Zhang J, Cao K, Yang B and Wu L: Calcium and polyamine regulated calcium-sensing receptors in cardiac tissues. Eur J Biochem 270: 2680-2688, 2003.

2. Lu FH, Tian Z, Zhang WH, Zhao YJ, Li HL, Ren H, Zheng HS, Liu C, Hu GX, Tian Y, et al: Calcium-sensing receptors regulate cardiomyocyte $\mathrm{Ca}^{2+}$ signaling via the sarcoplasmic reticulum-mitochondrion interface during hypoxia/reoxygenation. J Biomed Sci 17: 50, 2010.

3. Di Lisa F and Bernardi P: Mitochondria and ischemia-reperfusion injury of the heart: Fixing a hole. Cardiovasc Res 70 191-199, 2006

4. Grover GJ: Mitochondrial ATP-sensitive potassium channels and mitochondrial protein kinase C: Sometimes it's good to have a close neighbor. Am J Physiol Heart Circ Physiol 290: H1752-H1753, 2006.

5. Zheng H, Liu J, Liu C, Lu F, Zhao Y, Jin Z, Ren H, Leng X, Jia J, $\mathrm{Hu} \mathrm{G}$, et al: Calcium-sensing receptor activating phosphorylation of PKC $\delta$ translocation on mitochondria to induce cardiomyocyte apoptosis during ischemia/reperfusion. Mol Cell Biochem 358: 335-343, 2011.

6. Lu F, Tian Z, Zhang W, Zhao Y, Bai S, Ren H, Chen H, Yu X, Wang J, Wang L, et al: Calcium-sensing receptors induce apoptosis in rat cardiomyocytes via the endo(sarco)plasmic reticulum pathway during hypoxia/reoxygenation. Basic Clin Pharmacol Toxicol 106: 396-405, 2010.
7. Murriel CL, Churchill E, Inagaki K, Szweda LI and MochlyRosen D: Protein kinase Cdelta activation induces apoptosis in response to cardiac ischemia and reperfusion damage: A mechanism involving BAD and the mitochondria. J Biol Chem 279: 47985-47991, 2004.

8. Dong S, Teng Z, Lu FH, Zhao YJ, Li H, Ren H, Chen H, Pan ZW, Lv YJ, Yang BF, et al: Post-conditioning protects cardiomyocytes from apoptosis via PKC(epsilon)-interacting with calcium-sensing receptors to inhibit endo(sarco)plasmic reticulum-mitochondria crosstalk. Mol Cell Biochem 341: 195-206, 2010.

9. Churchill EN and Mochly-Rosen D: The roles of PKCdelta and epsilon isoenzymes in the regulation of myocardial ischaemia/reperfusion injury. Biochem Soc Trans 35: 1040-1042, 2007.

10. Kostyak JC, Hunter JC and Korzick DH: Acute PKCdelta inhibition limits ischaemia-reperfusion injury in the aged rat heart: Role of GSK-3beta. Cardiovasc Res 70: 325-334, 2006.

11. Parihar SP, Ozturk M, Marakalala MJ, Loots DT, Hurdayal R, Beukes D, Van Reenen M, Zak DE, Mbandi SK, Darboe F, et al: Protein kinase C-delta (PKCD), a marker of inflammation and tuberculosis disease progression in humans, is important for optimal macrophage killing effector functions and survival in mice. Mucosal Immunol 11: 579-580, 2018.

12. Li Q, Park K, Xia Y, Matsumoto M, Qi W, Fu J, Yokomizo H, Khamaisi M, Wang X, Rask-Madsen C and King GL: Regulation of macrophage apoptosis and atherosclerosis by lipid induced PKCס isoform activation. Circ Res 121: 1153-1167, 2017.

13. Wie SM, Wellberg E, Karam SD and Reyland ME: Tyrosine kinase inhibitors protect the salivary gland from radiation damage by inhibiting activation of protein kinase $C-\delta$. Mol Cancer Ther 16: 1989-1998, 2017.

14. Qi X, Vallentin A, Churchill E and Mochly-Rosen D: deltaPKC participates in the endoplasmic reticulum stress-induced response in cultured cardiac myocytes and ischemic heart. J Mol Cell Cardiol 43: 420-428, 2007.

15. Qi X and Mochly-Rosen D: The PKCdelta-Abl complex communicates ER stress to the mitochondria-an essential step in subsequent apoptosis. J Cell Sci 121: 804-813, 2008.

16. Mayhew TM,Lucocq JM and Griffiths G: Relative labelling index: A novel stereological approach to test for non-random immunogold labelling of organelles and membranes on transmission electron microscopy thin sections. J Microsc 205: 153-164, 2002.

17. Chimenti S, Carlo E, Masson S, Bai A and Latini R: Myocardial infarction: Animal models. Methods Mol Med 98: 217-226, 2004.

18. Davey KA, Garlick PB, Warley A and Southworth R: Immunogold labeling study of the distribution of GLUT-1 and GLUT-4 in cardiac tissue following stimulation by insulin or ischemia. Am J Physiol Heart Circ Physiol 292: H2009-H2019, 2007.

19. Ding JW, Tong XH, Yang J, Liu ZQ, Zhang Y, Yang J, Li S and Li L: Activated protein C protects myocardium via activation of anti-apoptotic pathways of survival in ischemia-reperfused rat heart. J Korean Med Sci 25: 1609-1615, 2010.

20. Zhao GL, Yu LM, Gao WL, Duan WX, Jiang B, Liu XD, Zhang B, Liu ZH, Zhai ME, Jin ZX, et al: Berberine protects rat heart from ischemia/reperfusion injury via activating JAK2/STAT3 signaling and attenuating endoplasmic reticulum stress. Acta Pharmacol Sin 37: 354-367, 2016.

21. Kockskämper J, Zima AV, Roderick HL, Pieske B, Blatter LA and Bootman MD: Emerging roles of inositol 1,4,5-trisphosphate signaling in cardiac myocytes. J Mol Cell Cardiol 45: 128-147, 2008.

22. Mao W, Iwai C, Qin F and Liang CS: Norepinephrine induces endoplasmic reticulum stress and downregulation of norepinephrine transporter density in PC12 cells via oxidative stress. Am J Physiol Heart Circ Physiol 288: H2381-H2389, 2005.

23. Kaur K, Singh M, Singh N and Jaggi AS: Possible mechanism of rottlerin induced modulation of ischemia reperfusion injury in isolated rat hearts. Biol Pharm Bull 31: 1745-1748, 2008.

24. Hernández-Bedolla MA, González-Domínguez E, ZavalaBarrera C, Gutiérrez-López TY, Hidalgo-Moyle JJ, VázquezPrado J, Sánchez-Torres C and Reyes-Cruz G: Calciumsensing-receptor (CaSR) controls IL-6 secretion in metastatic breast cancer MDA-MB-231 cells by a dual mechanism revealed by agonist and inverse-agonist modulators. Mol Cell Endocrinol 436: 159-168, 2016.

25. Sano R and Reed JC: ER stress-induced cell death mechanisms. Biochim Biophys Acta 1833: 3460-3470, 2013.

26. Lv Z, Liu C, Zhai M, Zhang Q, Li J, Zheng F and Peng M: LPS pretreatment attenuates cerebral ischaemia/reperfusion injury by inhibiting inflammation and apoptosis. Cell Physiol Biochem 45: 2246-2256, 2018. 
27. Liu C, Fu Q, Mu R, Wang F, Zhou C, Zhang L, Yu B, Zhang Y, Fang $\mathrm{T}$ and Tian F: Dexmedetomidine alleviates cerebral ischemia-reperfusion injury by inhibiting endoplasmic reticulum stress dependent apoptosis through the PERK-CHOP-Caspase-11 pathway. Brain Res 1701: 246-254, 2018.

28. Zhang M, Wu A, Shen Y, Chen H, Tu J and Zhai C: Effects of L-carnitine and bisoprolol on endoplasmic reticulum stress-mediated myocardial injury after cardiopulmonary resuscitation in rats. Zhonghua Yi Xue Za Zhi 95: 1475-1478, 2015 (In Chinese).

29. Zhang L, Zhang H, Lv M, Jia J, Fan Y, Tian X, Li X, Li B, Ji J, Wang L, et al: Increased expression of $78 \mathrm{kD}$ glucose-regulated protein promotes cardiomyocyte apoptosis in a rat model of liver cirrhosis. Int J Clin Exp Pathol 8: 9256-9263, 2015.

30. Xuan LY, Tao XX, Zhao YJ, Ge HY, Bao LH, Wang DP and Zhao M: Effect of total flavonoids of astragalus on endoplasmic reticulum chaperone, calumenin and connecxin 43 in suckling mouse myocardium with myocarditis caused by coxsackievirus B3. Zhongguo Ying Yong Sheng Li Xue Za Zhi 32: 51-54, 2016 (In Chinese).
31. Fu HY, Sanada S, Matsuzaki T, Liao Y, Okuda K, Yamato M, Tsuchida S, Araki R, Asano Y, Asanuma H, et al: Chemical endoplasmic reticulum chaperone alleviates doxorubicin-induced cardiac dysfunction. Circ Res 118: 798-809, 2016.

32. Tabas I and Ron D: Integrating the mechanisms of apoptosis induced by endoplasmic reticulum stress. Nat Cell Biol 13: 184-190, 2011.

33. Iurlaro R and Muñoz-Pinedo C: Cell death induced by endoplasmic reticulum stress. FEBS J 283: 2640-2652, 2016.

34. Chen H, Yang H, Pan L, Wang W, Liu X, Ren X, Liu Y, Liu W, Zhang Y, Jiang L, et al: The molecular mechanisms of XBP-1 gene silencing on IRE1 $\alpha$-TRAF2-ASK1-JNK pathways in oral squamous cell carcinoma under endoplasmic reticulum stress. Biomed Pharmacother 77: 108-113, 2016.

35. Davis RJ: Signal transduction by the JNK group of MAP kinases. Cell 103: 239-252, 2000.

36. Brandt B, Abou-Eladab EF, Tiedge $M$ and Walzel $\mathrm{H}$ : Role of the JNK/c-Jun/AP-1 signaling pathway in galectin-1-induced T-cell death. Cell Death Dis 1: e23, 2010. 